Copyrights@ Balitar Islamic University, Blitar, Indonesia; Http://jares.unisbablitar.ejournal.web.id Citation: Brillian Pintakami, Lintar . 2017. Gender Roles In Optimisation Of House-Yard Land To Improve Household Income. JARES, (2017), 2(1): 1-15

\title{
GENDER ROLES IN OPTIMISATION OF HOUSE-YARD LAND TO IMPROVE HOUSEHOLD INCOME \\ (Case Study of Kampung Kucai in Kranggan Hamlet, Pojok Village, Blitar Regency)
}

\author{
Lintar Brillian Pintakami \\ Lecturer in Agribusiness Program, Faculty of Agriculture, Balitar Islamic University \\ email: lintarbrillianpintakami@unisbablitar.ac.id
}

\begin{abstract}
This research aims to describe women farmer's participation in the establishment of Kampung Kucai (Chives Hamlet) through Women Farmers Group, to identify existing gender roles, and to review to what extent do women contribute to household income by means of house-yard land optimisation for farming practice. Study area was determined purposively in Kampung Kucai, Kranggan Hamlet, Pojok Village, Blitar Regency. This research was conducted between March and April 2018. Snowball sampling was used as sampling method. There were 20 respondents interviewed, both husbands and wives actively involved in Women Farmers Group, and 5 key informants. Data were analysed using descriptive analysis with qualitative and quantitative approaches. It was found that women's participation in the Kampung Kucai's establishment made up from chives cultivation, promotional activities, and managing sustainably. Gender roles in the house-yard land chives farming management were identified according to role/activity, control, access, and benefit disparities between men and women. Men were found to have allocated more time on productive role compared to their women counterparts. Men allocated 10 hours per day or $66,7 \%$ worth productive role where women allocated 5 hours per day or $33,3 \%$. Therefore, each contributions to household income per month were Rp. 460.230,- and Rp. 229.770 ,- respectively, whereas women allocated more reproductive role than their men counterparts at $50 \%$ rate compared to $14,5 \%$.
\end{abstract}

Keywords: Gender Roles, Women Farmer, Workloads, Income Contribution.

Received: 26 February, 2017; Accepter: 15 March, 2017

\section{INTRODUCTION}

Known as agrarian country, most Indonesian relies on agricultural sector for their livelihood. Acording to Chief Central Statistical Agency (BPS), as cited in Tempo (2017), 39,68 millions of population or 31,86 percent of national workforce, work in the agricultural fields. The national development goals through government-initiated policy are by improving community's economic level through agricultural development (Ningtyas, 2013). The BPS recorded the population growth rate has reached 1,36 percent with \pm 30 million of population increase during 2010-2016, and the degrading of national farm area since 2013 (BPS, 2017). The population increase and the limited availability of land nowadays has challenges creative mind set and actions in effort to design innovative agribusiness practices, considering its strategic role particularly to 
provide food, shelter, clothing, and energy for the community (Rahayu in Marhalim, 2015).

Utilising house-yard land has been a strategic innovative agribusiness approach typically for housewives (Yulida, 2013). Moreover, Ashari (2012) suggested that good utilisation of house-yard would provide further benefits, such as additional economic income. In most community's perspective, women's role are "merely" housewives and mother, and considered less contributive to household income (Handayani. 2009). By optimalising house-yard land, it was expected to provide opportunities to housewives to make better use of leisure time through agricultural farming so as to provide additional income to households (Ashari, 2012; Puspitasari, Puspitawati, and Herawati, 2013; Yulida, 2013).

Rosmini (2007) stated that women by their role at home as personal, spouse, and housewife has also important share as decision maker if creative chance are given. One government program to allow creative work of women are the establishment of Women Farmers Group. This organisation aims to improve and develop farmers and their family's capability as agricultural development subject through a group approach so they would be contributive to national growth. Women Farmers Group Al-Afiah, AnNisa, and Manfaat are active farmers' groups in developing women's participation through optimalising house-yard land. Engaged by housewives, the group pioneered the Kampung Kucai in Kranggan Hamlet, Pojok Village, Blitar Regency, since 2013.

Kucai/chives (Allium tuberosum) were selected commodity due to its relatively easy cultivation process, short harvest period, require little space, and its visual similarity to puzzlegrass making it considerable as ornamental yard plant, so that it has both economic and aesthetic value. According to Kaska, Celebi Toprak, and Alan (2017), chives are considered ornamental plant popular as culinary product as well as traditional medicine in some East Asian countries.

Women's role in chives farming management are expected to provide positive impact in increasing household income. Despite generally in fact, the involvement of women farmer have been considered only as means of "supportive" participation to patriarch (farmer) and lacking equity means as decision maker, so that their contribution towards household income has nearly not taken into account (Rosmini, 2007). Making use of house-yard land are inseparable to the importance of family member's role either the wives and husbands in capturing job opportunities, increasing income, and providing added value to their family community life.

Built upon the earlier background, this study will: discuss women's participation through Women Farmers Group in establishing Kampung Kucai, identify gender roles in house-yard chive farming management, and review to what extent do women contribute to household income by means of house-yard land optimisation for farming practice in Kampung Kucai. This research attempts to challenge the existing gender bias particularly the negatively stigmatised housewives' role. 


\section{METHODS}

Study area determined by purposive approach in Kampung Kucai, Kranggan Hamlet, Pojok Village, Blitar Regency, based on consideration that the site has notably awarded a first place at municipal level as Desa Berseri (Clean, Healthy, Sustainable Village) in 2017. The study was conducted from March to April 2018. Primary data were collected via Focused Group Discussion (FGD) with Women Farmers Group established in Kranggan Hamlet, i.e. Al-Afiah, An-Nisa, and Manfaat. In-depth interviews were done with Kranggan Village Headman, and the administrators and members of Women Farmers Group. Participatory observation were performed by direct sighting towards gender roles in optimalising house-yard land to increase house hold income. Secondary data were obtained from Pojok Village Office and Secretary Office of Women Farmers Group. Snowball technique was adopted as sampling method. There were 20 respondents of both wives and husbands actively involved in Kampung Kucai's Women Farmers Group. In addition, 5 key informant were also invited purposively, including: formal and informal community leader, village officials, and Women Farmers Group's administrators in Kampung Kucai.

Qualitative descriptive analysis method were used to describe women farmer's participation pioneering the Kampung Kucai and to describe gendered roles in the chive farming management (Pintakami, 2013). By using Harvard Model gender analysis, women farmer's role were examined through four analytical category: activity profile (productive, reproductive, and societal activities), access profile, control profile, and benefit profile.

Quantitative descriptive analysis method were used to examine women's contribution towards household income through house-yard optimalisation for chive farming management in Kampung Kucai. Household's net income are equal to total earnings from both agricultural sector, and non-agricultural sectors (if husbands works as so). Income analysis or profits are calculated through subtracting household's total income by total expenses during one month interval, using the following formula:

$$
\pi=\mathrm{TR}-\mathrm{TC}
$$

Where:

$$
\begin{array}{ll}
\pi & =\text { Income }(\mathrm{Rp}) \\
\mathrm{TR} & =\text { total revenue }(\mathrm{Rp}) \\
\mathrm{TC} & =\text { total cost }(\mathrm{Rp})
\end{array}
$$

Furthermore, to examine women farmer's income towards household, contribution analysis were calculated. According to Hernanto (1984) women's income contribution towards household can be calculated using the following:

$$
\mathrm{K}=\frac{Y w}{Y t} \times 100 \%
$$


Where:

$\mathrm{K}=$ Women farmer's income contribution (\%)

$\mathrm{Yw}=$ Women farmer's workload doing productive role (hours)

$\mathrm{Yt}=$ Total workload of productive role (hours)

\section{RESULTS AND DISCUSSIONS}

\subsection{Women Farmers' Participation in Pioneering Kampung Kucai.}

Women's played crucial role in pioneering the Kampung Kucai. Started from unproductive house-yard, a local women through Women Farmers Group inspired Kranggan Hamlet housewives to utilise their house-yard for chive farming. This supports Anthopoulo's (2010) argument that women's participation particularly in the restructuring of rural area would significantly contribute to the creation of livelihoods that enable households to maintain themselves in rural areas.

Women farmers were also participated in agricultural inputs preparation such as seeds and seedlings. Initially, seeds were obtained during comparative study in Batu, before the farmer group's member start to independently establish chive nurseries. Successful grown seeds were distributed among group's member, 10 polybags each to be further planted and reproduced. The Women Farmers Group has successfully spread the chive plantations among households, making the locals now recognised as Kampung Kucai (Chives Hamlet). In 2017, Al-Afiah and An-Nisa groups received Baitul Maal's grants worth 1800 seedlings. The grants were distributed among the deprived group member (generate less than Rp. 1.000.000,- monthly income). There were 20 recipients of the grants, taken from 10 members of Al-Afiah and An-Nisa respectively, who later formed "Manfaat" farmers group to simplify controls to the seedling grants farming.

Attempts to promote Kampung Kucai were made by participating in numbers of competitions, one of which were Desa Berseri (Clean, Healthy, Sustainable Village) competition organised by local authority's environmental service agency (DLH) in 2017 where Kampung Kucai won the first price. As an effort to increase awareness towards Kampung Kucai's sustainable management, visit studies were conducted by women farmers in Batu, Tulungagung, and Ngawi, focusing on planting method, growth media rotation, organic fertiliser production, seeds quality sorting, nurseries building, and plant-care techniques. Moreover, routine coaching were also provided by Agriculture Agency, family welfare fostering (PKK), and Blitar Pancasila Youth Social Foundation.

\subsection{Identification of Gender Role in House-yard Chive Farming Management.}

Murniati (2004) stated that work division in community are divided into three main groups: productive, reproductive, and societal, and from these, the communities determine their human role. To identify gender role in house-yard chive farming, analysis were performed according to role/activity, control, access, and benefit disparities between men and women. 


\section{a. Role/activity profile disparities.}

Disparities in activity role commonly based on money-generating work, family caretaking, social engagement, religious activities, parties, or politics which related to decision making (Handayani, 2009; Buvinic in Rosmini, 2007). These role disparities among men and women, commonly consists of: 1) productive role, a money (or money exchangeable goods)-generating work; 2) reproductive role: activities related to housekeeping and caretaking; and 3) societal role: community-based activities characterised by building solidarity and togetherness among the members of society (Puspitawati, 2013 and Sudarta, 2007).

Women farmer's productive role in Kampung Kucai are divided into two: economic productive activity (cash) and no-economic (natura). According to Putri (2007), women's workload generally include wage-generating economic activities, and non-economic activities including basics, social, and housewives role. In the following disparities in economic productive work between men and women in hose-yard chive farming are shown.

Table 1. Work Division in Chive House-Yard Farming

\begin{tabular}{|c|c|c|c|c|}
\hline No. & Activities & Men & Women & Both \\
\hline 1. & Seeding & & & $\checkmark$ \\
\hline 2. & Planting & & $\checkmark$ & \\
\hline 3. & Fertilising & & $\checkmark$ & \\
\hline 4. & Weed control & & $\checkmark$ & \\
\hline 5. & Pest and disease control & & $\checkmark$ & \\
\hline 6. & Harvest & & $\checkmark$ & \\
\hline 7. & Post-harvest & & & $\checkmark$ \\
\hline 8. & Marketing & & & $\checkmark$ \\
\hline
\end{tabular}

Table 1 showed that most farming activities were done by women farmers, except for some heavy work where men power are needed such as land plowing and bedding, plantation media preparing, nursery and seed rack building in the seeding phase. Other activities that require men's contribution are in the post-harvest and marketing. In the post-harvest, husbands help wives in quality sorting prior to yield collection by Women Farmers Group coordinator. In the marketing section, husbands and wives work together on daily basis. There are 8 person every day, 3 men and 5 women alternately chosen from Women Farmers Group, involved in the marketing of chive harvests to local markets in Blitar. Some of which including Leg imaret, Templek market, Pon market, and Balapan market.

Plantation are done by women (Figure 1). This includes seedling transfer to polybag or used paint cans. Alternatively, for those whose yards are wide enough, chives were planted directly on front yard. Men are not involved in this stage. 


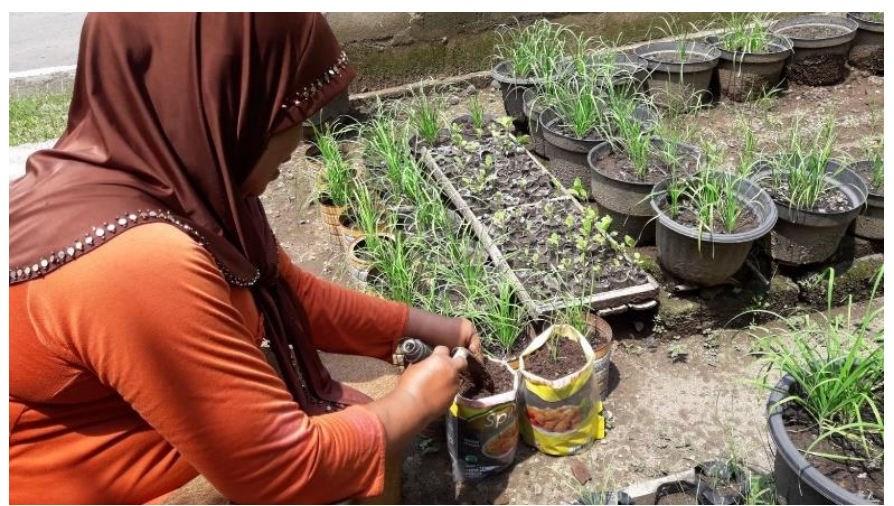

Figure 1. Chives planting by women farmer

Fertilising and weed control were also done by women. NPK fertiliser are applied at replanting stage, 15 days post-planting, and continued monthly with added organic manure. Weed controls are done daily (Figure 2).

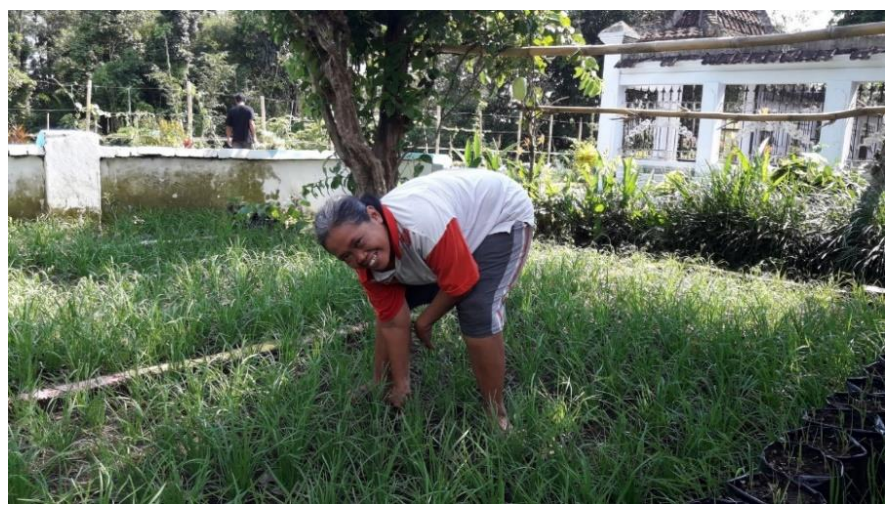

Figure 2. Weeding by women farmer

Harvest stage are done entirely by women, once or twice per day (during early dawn and afternoon) depends on market demands. The yields are distributed to Legi market, Pon market, and Balapan market.

Non-economic productive activity (natura) are activities done by men and women farmer in Kranggan Hamlet in taking benefits from natural resource costlessly. Those are include utilisation of harvest left-over for domestic consumption, maintaining its economic value. Recycling used paint cans were also considered non-economic productive activity. Using cans as plant's pot are more durable and environmentally friendly.

In ensuring household's welfare, reproductive roles are one of the crucial activities worth considering. Despite generating no direct cash, these roles are irreplaceable (Pintakami, 2013). Reproductive activities in study area are predominated by women. As argued by Hadiprakoso (2005), if biologically women are able to get pregnant, then do a labor, so that women have gendered role as child's caretaker, sitter, and educator, then it's inarguable. However the problems are the long-forming gender disparities creating the so-called stereotype that "women are belong inside the house" (Williams, 2018), that wives are solely responsible for baby-sit. 
Table 2. Gendered Roles in Reproductive Activities

\begin{tabular}{|c|c|c|c|c|}
\hline No. & Activities & Men & Women & Both \\
\hline & $\begin{array}{l}\text { Child-care: } \\
\text { - Baby-sit } \\
\text { - School preparing } \\
\text { - Helping with homework }\end{array}$ & & $\begin{array}{l}\checkmark \\
\checkmark \\
\checkmark\end{array}$ & \\
\hline 2. & Cooking & & $\checkmark$ & \\
\hline 3. & House cleaning & & & $\checkmark$ \\
\hline 4. & Shopping & & $\checkmark$ & \\
\hline 5. & Laundering and dishwashing & & & $\checkmark$ \\
\hline
\end{tabular}

Societal activities in Kranggan Hamlet are considered as mandatory, especially if it holds mutual interests between communities for example: in Kerja Bakti (community work), men and women are both responsible. An important moments are when the village are to be designated as pilot village representing the municipality, all community member will work together. Table 3 showed societal activities of men and women in Kranggan Hamlet.

Table 3. Gendered Role in Societal Community Activities

\begin{tabular}{|c|c|c|c|c|}
\hline No & Activities & Men & Women & Both \\
\hline 1. & $\begin{array}{l}\text { Formal } \\
\text { - PKK (family welfare fostering) } \\
\text { - PNPM (National Programs for Community } \\
\text { Empowerment) } \\
\text { - Bimdu (Integrated mentoring) } \\
\text { - Posyandu (Integrated service post) } \\
\text { - Farmers group }\end{array}$ & $\checkmark$ & $\checkmark$ & $\begin{array}{l}\checkmark \\
\checkmark\end{array}$ \\
\hline 2. & $\begin{array}{l}\text { Non-Formal } \\
\text { - Religious meeting } \\
\text { - Arisan } \\
\text { - Kerja Bakti } \\
\text { - Aerobic } \\
\text { - General help: (marriage, circumcision, help } \\
\text { in distress) }\end{array}$ & & $\begin{array}{l}\checkmark \\
\checkmark\end{array}$ & $\begin{array}{l}\checkmark \\
\checkmark\end{array}$ \\
\hline
\end{tabular}

Table above showed how men and women mutually involved in either formal or non-formal societal activities. While most formal activities involve women, PNPM are participated only by men due to the physical-type work related to infrastructure grants. In non-formal activities, men and women share equal opportunity. 
Table 4. Women's Daily Schedule in Kampung Kucai

\begin{tabular}{|c|c|c|}
\hline No & Hours & Descriptions \\
\hline 1. & $03.00-05.00$ & $\begin{array}{l}\text { Early wake up, praying, self-caring, laundering, cooking for } \\
\text { whole family members. }\end{array}$ \\
\hline 2. & $05.00-07.00$ & $\begin{array}{l}\text { Harvesting the chives for morning deposit, collected at farmer's } \\
\text { group coordinator. }\end{array}$ \\
\hline 3. & $07.00-08.00$ & $\begin{array}{l}\text { Preparing children's school needs, breakfast, taking kids to } \\
\text { school. }\end{array}$ \\
\hline 4. & $08.00-10.00$ & Doing activities in house-yard. \\
\hline 5. & $10.00-13.00$ & Joining societal activities. \\
\hline 6. & $13.00-15.00$ & Taking rest at home. \\
\hline 7. & $15.00-17.00$ & House-cleaning. \\
\hline 8. & $17.00-18.00$ & $\begin{array}{l}\text { Harvesting the chives for afternoon deposit, collected at } \\
\text { farmer's group coordinator. }\end{array}$ \\
\hline 9. & $18.00-19.00$ & Preparing dinner and doing dishwashing \\
\hline 10. & $19.00-21.00$ & Helping kids for homework \\
\hline 11. & $21.00-03.00$ & Sleep \\
\hline
\end{tabular}

Productive, reproductive, and societal role division between men and women in a time management pattern are shown in table 4 (previous page) and table 5 below. Men's and women's daily schedules are listed to highlight some tasks done by each counterparts. These patterns are on general case. Work division of women in productive role are also followed by men's involvement in domestic role, although not as many as women's.

Table 5. Men's Daily Schedule in Kampung Kucai

\begin{tabular}{|c|c|c|}
\hline No & Hours & Descriptions \\
\hline 1. & $04.00-05.00$ & Wake up, praying, self-caring. \\
\hline 2. & $05.00-07.00$ & $\begin{array}{l}\text { Harvesting the chives for morning deposit, collected at farmer's } \\
\text { group coordinator. }\end{array}$ \\
\hline 3. & $07.00-08.00$ & Taking breakfast following by helping in dishwashing. \\
\hline 4. & $08.00-16.00$ & Doing non-agricultural work (casual laborer). \\
\hline 5. & $16.00-17.00$ & Taking rest. \\
\hline 6. & $17.00-18.00$ & $\begin{array}{l}\text { Harvesting the chives for afternoon deposit, collected at } \\
\text { farmer's group coordinator. }\end{array}$ \\
\hline 7. & $18.00-19.00$ & Helping with and joining dinner. \\
\hline 8. & $19.00-21.00$ & Joining societal activities. \\
\hline 9. & $21.00-04.00$ & Sleep \\
\hline
\end{tabular}

Workforce are time proportion used for work doing particular activities both in agricultural or non-agricultural sectors. Workloads depends of the type of work done but in contrary, some works require limited time (Nurmanaf, 2006). Women's workloads are greater on reproductive role, which accounted for $50 \%$ or 8 hours a day, while their productive and societal roles are $31 \%$ and $19 \%$ respectively. Table 6 showed how women generally plays role as both housewives and breadwinner, done on daily basis reflected in their workload allocations. 
Table 6. Women's Workloads

\begin{tabular}{clcc}
\multirow{2}{*}{ No } & \multirow{2}{*}{ Workload Type } & \multicolumn{2}{c}{ Descriptions } \\
\cline { 3 - 4 } & & Hours spent & Percentage (\%) \\
\hline 1. & Productive Role & 5 & 31 \\
2. & Reproductive Role & 8 & 50 \\
3. & Societal Role & 3 & 19 \\
\hline
\end{tabular}

Men's workload are listed in table 7, predominated in productive role accounted for $71 \%$ or 10 hours per day. Men share equal value for reproductive and societal role which accounts for $14,5 \%$ or 2 hours per day. It was found that men dedicate much lesser time for productive role compared to their women counterparts. These are correlative to general perception which claims reproductive roles are women's.

Table 7. Men's Workloads

\begin{tabular}{clcc}
\multirow{2}{*}{ No } & \multicolumn{2}{c}{ Workload Type } & \multicolumn{2}{c}{ Descriptions } \\
\cline { 3 - 4 } & & Hours spent & Percentage (\%) \\
\hline 1. & Productive Role & 10 & 71 \\
2. & Reproductive Role & 2 & 14,5 \\
3. & Societal Role & 2 & 14,5 \\
\hline
\end{tabular}

\section{b. Disparities in access and control profile towards resources.}

Access illustrates to what extent do men and women have opportunity to interact with existing resources. Control is the ability to retain such natural resource, giving the chance for decision making to it. Fisher (2012) highlighted that women's membership in farmer groups increases women's probability of keeping control over revenues and positively affects female-controlled income share. These kind of farmer's groups have the potential to promote smallholder commercialization in a gender equitable way. Table 8 below showed access and control disparities between men and women, towards various resources.

Tabel 8. Gendered Access and Control towards Resources

\begin{tabular}{|c|c|c|c|c|}
\hline No & Access and Control to & Men & Women & Both \\
\hline 1. & $\begin{array}{l}\text { Information: } \\
\begin{aligned} \text { - } & \text { Agriculture } \\
\text { - } & \text { Market } \\
\text { - } & \text { Health service }\end{aligned}\end{array}$ & $\checkmark$ & & $\checkmark$ \\
\hline 2. & $\begin{aligned} \text { Organisation: } \\
-\quad \text { Village government } \\
-\quad \text { Farmer's group } \\
-\quad \text { PKK (Family welfare fostering) }\end{aligned}$ & & $\checkmark$ & $\begin{array}{l}\checkmark \\
\checkmark\end{array}$ \\
\hline 3. & $\begin{array}{l}\text { Finance: } \\
\quad-\quad \text { Farm Business Credit }\end{array}$ & & & $\checkmark$ \\
\hline
\end{tabular}


4. Natural resources:

- House-yard land

- Water springs

The table above showed that men and women have equal access and control towards agricultural and health information, whereas market information are accessible by men since it require more effort and time doing market survey for chive yields. Organisational access and controls are also balanced, except for PKK which is originally dedicated for women/housewives involving community and children approach.

Access and control towards financial/farming business credits are obtainable by men or women, in the forms of savings and loans opportunity through farmer's group or Woman Farmer's Group. Regarding natural resources, everyone gain equal access to house-yard farming and water spring. Figure 3 pictures pilot plantation of Kranggan's chives where a well is available for water resource.

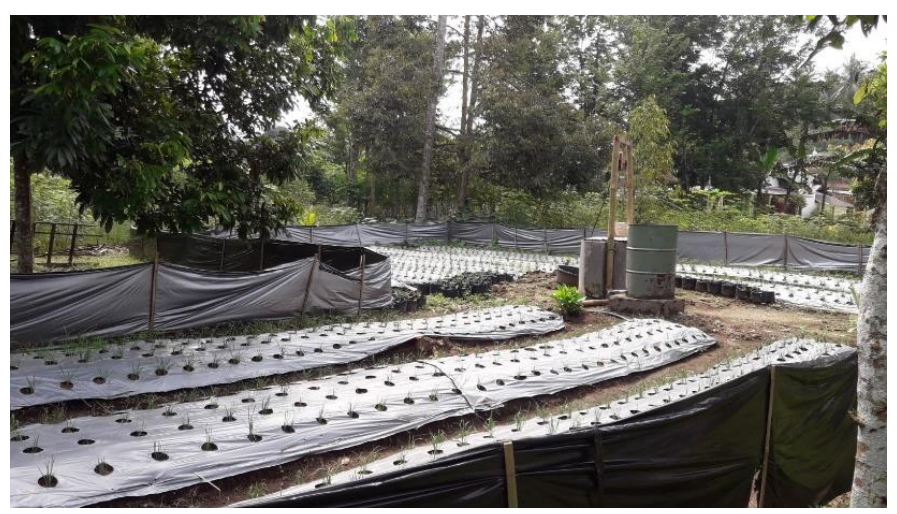

Figure 3. Pilot chive plantation in Kampung Kucai with well visible.

\section{c. Disparities in benefit profile}

Benefit aspects are opportunities to obtain certain benefits as the results of gendered work division. Benefit access including chance to obtain experiences and skills (Table 9.). Men and women share experienced benefits, as equal accesses to farmer's group are achieved. Experiences are also gained from chive farming activities through agribusiness institutional support which were established to aid, to serve, and to develop the farming practices. Among supporting services are include: Women Farmers Group (Al-Afiah, An-Nisa, and Manfaat), agricultural agency, Baitul Maal, and the Youth Social Foundation of Pancasila.

Table 9. Benefits According to Gender.

\begin{tabular}{clccc} 
No & Forms of Benefits & Men & Women & Both \\
\hline 1. & Experiences & & $\checkmark$ \\
2. & Skills & $\checkmark$ & \\
\hline
\end{tabular}




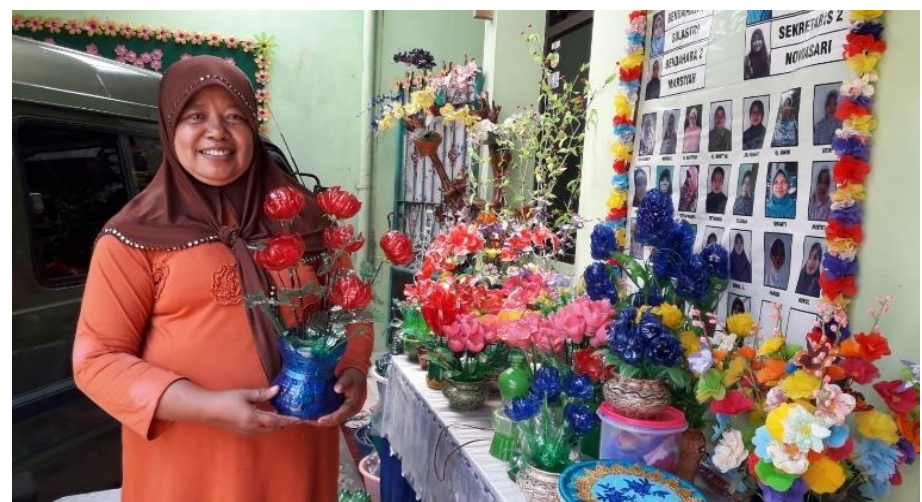

Figure 4. Skills in recycling inorganic wastes

Skills benefits are perceived by women. Since their pioneering to Kampung Kucai, the local authorities has express more attention promote the locals to participate in competitions at municipal and national level. Thenceforth, mentoring has always given through Women Farmers Group to further develop Kampung Kucai's potential. Skills benefits include planting ability and inorganic waste recycling. Women farmers has develop craftswomanship in reusing the recycled plastic bottles and bags to create useful products (Figure 4.).

\subsection{Women's contribution towards Household Income in Kampung Kucai.}

Alston (2011) claimed that women contribute economically through agicultural engagement, non-agricultural revenues, social activities, and their exceptional domestic roles. In the study area, household revenues are generated from two sources: chives farming and husbands revenues from non-agricultural work such as being casual labor as builder, carpenter, or turner. Table 10 showed lists of average monthly revenue, cost, and income of Kampung Kucai households.

Table 10. Detailed Househould Income Calculations

\begin{tabular}{|c|c|c|c|}
\hline No & Description & Unit & $\begin{array}{c}\text { Monthly Average } \\
\text { (Rupiah) }\end{array}$ \\
\hline \multicolumn{4}{|c|}{ Household Revenues } \\
\hline \multirow[t]{2}{*}{1} & Agricultural Sector & & \\
\hline & Chives production@ Rp.6.000,- & $50 \mathrm{~kg}$ & 300.000 \\
\hline \multirow[t]{2}{*}{2} & Non-agricultural Sector & & \\
\hline & Casual Labor@ @p. 65.000,- & $25 \mathrm{HOK}$ & 1.625 .000 \\
\hline \multicolumn{3}{|c|}{$\begin{array}{r}\text { Total Revenue } \\
\end{array}$} & 1.925 .000 \\
\hline \multicolumn{4}{|c|}{ Household Costs } \\
\hline \multicolumn{4}{|c|}{1 Agricultural Sector } \\
\hline a. & Polybags & 1 pak & 10.000 \\
\hline b. & Fertiliser (NPK) & $1 / 2 \mathrm{~kg}$ & 8.000 \\
\hline c. & Manures & $25 \mathrm{~kg}$ & 5.000 \\
\hline d. & Liquid pesticide & $5 \mathrm{~kg}$ & 10.000 \\
\hline e. & Other costs & & 25.000 \\
\hline \multicolumn{3}{|c|}{ Total } & 58.000 \\
\hline
\end{tabular}




$\begin{array}{ll}2 & \text { Household expenses } \\ \text { a. } & \text { Rice }(10 \mathrm{Kg} / \mathrm{month}) \\ \text { b. } & \text { Shopping (foods) } \\ \text { c. } & \text { Schooling needs } \\ \text { d. } & \text { Electricity } \\ \text { e. } & \text { Communication } \\ \text { f. } & \text { Gas }\end{array}$

Total

$$
\begin{gathered}
100.000 \\
600.000 \\
250.000 \\
100.000 \\
50.000 \\
18.000
\end{gathered}
$$

\section{Societal expenses}

a. Mentoring dues

b. Membership dues

c. Other societal needs

\subsubsection{0}

\begin{tabular}{cc} 
Total & $\mathbf{5 9 . 0 0 0}$ \\
\hline Total Cost & $\mathbf{1 . 2 3 5 . 0 0 0}$ \\
\hline $\begin{array}{c}\text { Household Income } \\
(\boldsymbol{\pi}=\text { TR- TC })\end{array}$ & $\mathbf{6 9 0 . 0 0 0}$ \\
\hline
\end{tabular}

Average monthly women farmer's household revenues are Rp. 1.925.000,-, sourced from chive farming and non-agricultural work combined. In line with Yuliati (2015), rural household revenues came from both agricultural and non-agricultural sector. Household costs are to cover expenses in agricultural production, family spending of average 4 person per farmer household (according to latest local census by village headman, 5 April 2018), and societal expenses, summed up to Rp. 1.235.000,per month.

Household's net income are calculated by subtracting household's total income by total expenses during one month interval. Chive farmer's household earned Rp. $690.000,-$ worth net income in average per month. This amounts are allocated for savings and precaution for future incidental needs.

Women farmer's contribution to household's income are accounted from the proportion of workloads or allocated time in productive role per total workloads of men's and women's productive role combined, times household's total income. Table 11 below describe monthly income contribution of women farmers.

Table 11. Contributions to Househould Income

\begin{tabular}{llccc} 
No & Description & Allocated Productive Role & $\begin{array}{c}\text { Contribution towards Profit } \\
\text { (Rp/month) }\end{array}$ \\
\cline { 3 - 5 } & Hours & $\begin{array}{c}\text { Percentage } \\
(\%)\end{array}$ & $\begin{array}{c}\text { (\%) } \\
\text { 1. Women }\end{array}$ \\
2. & Men & 10 & 33.3 & 229.770 \\
\hline
\end{tabular}

Men allocated more productive role than their women counterparts by 5 working hours gap or 33,3\%, thus valued higher monetary profit. As Nurmayasari (2014) argued, women's contribution in the economic process are capable of improving family welfare, particularly in a well-being family. In a deprived household, women dedicate distinct contribution to maintain family welfare. 
Generally men accounted twice as much productive work compared to women. However, women are capable to dedicate significant time and efforts to perform their reproductive role while maintaining their productive role compared to their men counterparts. Moreover, women farmers are capable to preserve time balance to stay actively involved in societal work for a little more time than men (Table 6).

\section{CONCLUSION}

Women played crucial role in pioneering the Kampung Kucai. Women through Women Farmers Group inspired Kranggan Hamlet housewives to utilise their houseyard for chive farming. Women farmers were also participated in agricultural inputs preparation such as seeds and seedlings. As an effort to increase awareness towards Kampung Kucai's sustainable management, visit studies were conducted by women farmers. Women's workloads are greater on reproductive role, which accounted for 50 $\%$ or 8 hours a day, while their productive and societal roles are $31 \%$ and $19 \%$ respectively. Men's workload are predominated in productive role accounted for $71 \%$ or 10 hours per day. Men share equal value for reproductive and societal role which accounts for $14,5 \%$ or 2 hours per day. It was found that men dedicate much lesser time for productive role compared to their women counterparts. Men and women share experiences benefits, as equal access to farmer's group are achieved. Skills benefits are perceived by women. Skills benefits include planting ability and inorganic waste recycling. Women farmers has develop craftswomanship in reusing the recycled plastic bottles and bags to create useful products. Average monthly women farmer's household revenues are Rp. 1.925.000,-, sourced from chive farming and non-agricultural work combined. Men allocated more productive role than their women counterparts by 5 working hour gap or $33,3 \%$, thus valued higher monetary profit. Generally men accounted for twice as much productive work compared to women. However, women are capable to dedicate significant time and efforts to perform their reproductive role while maintaining their productive role compared to their men counterparts. Moreover, women farmer are capable to preserve time balance to stay actively involved in societal work in a little more time than men.

\section{REFERENCES}

Alston, M., 2011. Gender and climate change in Australia. Journal of Sociology, 47(1), pp.53-70.

Anthopoulou, T., 2010. Rural women in local agrofood production: Between entrepreneurial initiatives and family strategies. A case study in Greece. Journal of Rural Studies, 26(4), pp.394-403.

Ashari, S. T., 2012. Potensi dan Prospek Pemanfaatan Lahan Pekarangan Untuk Mendukung Ketahanan Pangan. Jakarta: Pusat Sosial Ekonomi dan Kebijakan Pertanian Press.

BPS, 2017. Statistik Indonesia 2017. Jakarta: Badan Pusat Statistik Republik Indonesia.

Fischer, E.and Qaim, M., 2012. Gender, Agricultural Commercialization, and Collective Action in Kenya. Food Security, 4 (3), pp.441- 453. 
Hadiprakoso, A., 2005. Penguatan peran gender dalam pemberdayaan ekonomi keluarga miskin: Studi kasus kelompok Dasa Wisma Desa Sudagaran [tesis]. Bogor (ID): Institut Pertanian Bogor.

Handayani, 2009. Kontribusi Pendapatan Ibu Rumah Tangga Pembuat Makanan Olahan Terhadap Total Pendapatan Keluarga. Jurnal Kependudukan dan Pengembangan Sumber Daya Manusia, Volume V , 63.

Hernanto, F., 1984. Aspek- Aspek Pendapatan Ekonomi. Jakarta: Badan Penelitian Dan Pengembangan Pertanian.

Kaska, A., Celebi Toprak, F. and Alan, A.R., 2017. Morphological and Cytological Characterization of Gynogenic Garlic Chive (Allium tuberosum Rottler ex Spreng) Lines.

Murniati, N., 2004. Getar Gender/Perempuan Indonesia dalam Perspektif Sosial, Politik, Ekonomi, Hukumdan Ham. Magelang: Indonesiatera.

Ningtyas, B.R.., 2013. Dampak Pembangunan Sektor Pertanian Terhadap Perekonomian Jawa Timur: Studi Kasus Penerapan Model Input Output. Surabaya: Media Press.

Nurmanaf, A.R., 2006. Peranan Sektor Luar Pertanian terhadap Kesempatan Kerja dan Pendapatan di Pedesaan Berbasis Lahan Kering. SOCA: Socioeconomics of Agriculture and Agribusiness, 6(3).

Nurmayasari, D. and Ilyas, I., 2014. Peran Anggota Kelompok Wanita Tani (KWT) Laras Asri Pada Peningkatan Kesejahteraan keluarga (Studi Deskriptif di Dusun Daleman Desa Kadirejo kecamatan Pabelan Kabupaten Semarang). Journal of Nonformal Education and Community Empowerment, 3(2).

Pintakami, L.B., Yuliati, Y. and Purnomo, M., 2013. Keterlibatan Perempuan Tani Pada Program Pengelolaan Hutan Bersama Masyarakat (PHBM) Dalam Rangka Mencapai Kesejahteraan Rumah Tangga (Studi Kasus Di Desa Bayem, Kecamatan Kasembon, Kabupaten Malang). Indonesian Journal of Women's Studies, 1(1).

Puspitasari, N., Puspitawati, H. dan Herawati, T., 2013. Peran Gender, Kontribusi Ekonomi Perempuan, dan Kesejahteraan Keluarga Petani Hortikultura. Jurnal Ilmu Keluarga \& Konsumen, 6(1), pp.10-19.

Rahayu, M., 2005. Keanekaragaman Tanamanan Pekarangan dan Pemanfaatannya di Desa Lampeapi, Pulau Wawoni, Sulawesi Selatan. Jakarta: Bidang Botani, Pusat Penelitian Biologi.

Rosmini, 2007. Keterlibatan Wanita Tani Pada Kegiatan Usahatani "Bawang Goreng Lokal Palu” Dalam Upaya Peningkatan Pendapatan Keluarga Di Kabupaten Donggala. Agroland 14 (3): 201 - 207.

Susilowati, S.H. and Maulana, M., 2016. Luas Lahan Usaha Tani dan Kesejateraan Petani: Eksistensi Petani Gurem dan Urgensi Kebijakan Reforma Agraria. Jakarta: Analisis Kebijakan Pertanian, 10(1), pp.17-30.

Tempo, 2017. Februari 2017, Sektor Pertanian Serap Banyak Tenaga Kerja. [online] https://bisnis.tempo.co/read/872715/februari-2017-sektor-pertanian-serapbanyak-tenaga-kerja. [diakses 12 April 2014]. 
Williams, W.W., 2018. The equality crisis: Some reflections on culture, courts, and feminism [1982]. In Feminist legal theory (pp. 13-34). Routledge.

Yuliati, Yayuk. dan Bhastoni1, Khamiliya, 2015. Peran Wanita Tani Di Atas Usia Produktif Dalam Usahatani Sayuran Organik Terhadap Pendapatan Rumah Tangga Di Desa Sumberejo Kecamatan Batu. Jurnal Habitat, Volume 26, No. 2, Agustus 2015, Hal. 119-129.

Yulida, R., 2013. Kontribusi Usahatani Lahan Pekarangan terhadap Ekonomi Rumah Tangga Petani di Kecamatan Kerinci Kabupaten Pelalawan. IJAE (Jurnal Ilmu Ekonomi Pertanian Indonesia), 3(2), pp.135-154. 